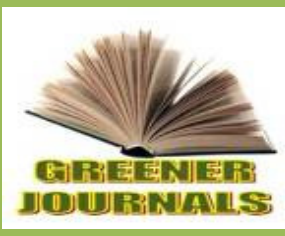

\title{
Utilization of Cassava in Poultry Feed in Guyana
}

\section{Motielal $\mathbf{M}^{1 *}$, Homenauth $\mathbf{O}^{1}$, DeGroot $\mathbf{P}^{2}$}

\author{
${ }^{1 *}$ Food Science and Nutrition, National Agricultural Research and Extension Institute Agriculture \\ Road, Mon Repos, East coast Demerara, Guyana. \\ ${ }^{1}$ Chief Executive Officer, National Agricultural Research and Extension Institute. \\ ${ }^{2}$ Chief Executive Officer, Bounty Farms Limited, Public Road, Timehri, East Bank Demerara, \\ Guyana.
}

ARTICLE INFO

Article No.: 022616047

DOI: 10.15580/GJAS.2016.3.022616047

Submitted: $26 / 02 / 2016$

Accepted: 07/02/2016

Published: 28/03/2016

${ }^{\star}$ Corresponding Author

Motielal M

E-mail: mmotielal@gmail.com

Keywords:

cassava, poultry feed, sun-dried, poultry
This study was initiated to determine the best ratio at which cassava meal could be incorporated in the diets of broiler chicks and the economic benefit of feeding cassava meal to broilers. For this investigation $1140 \mathrm{~kg}$ of fresh cassava tubers were sun-dried and converted to flour (composition determined). Eight hundred one day old chicks were selected for this trial. There were four treatments $(0 \%, 5 \%, 10 \% \&$ $15 \%$ Cassava meal) arranged accordingly to completely randomized design with two replicates. There were two hundred birds per treatment. All the chicks were given feed and water ad lib. The trial lasted for a period of six weeks. Body weights were taken weekly, mortality was recorded daily and the feed conversion ratio (FCR) was determined. The economic cost was calculated at the end of this trial. The results of this study indicated that cassava root meal canbe used as substitute for the rice or corn in conventional feed for poultry, provided that the cassava-based rations are balanced properly for all nutrients. The results of the study indicated that cassava can be included as an ingredient in poultry feed. The recommended amount is $15 \%$. 


\section{INTRODUCTION}

The agriculture sector in Guyana accounts for approximately $50 \%$ of foreign exchange earnings. This generates about $20.6 \%$ of the national GDP and employs approximately $40 \%$ of the labour force. The livestock sub-sector contributes approximately $13.6 \%$ of the agricultural GDP and $2.8 \%$ of the total GDP (N. Cumberbatch, National Agricultural Research \& Extension Institute, Guyana, observation).

This sub-sector is responsible for the production of poultry meat, eggs, beef, pork, mutton and milk. Guyana could be considered self-sufficient in livestock with the exception of milk (N. Cumberbatch, National Agricultural Research \& Extension Institute, Guyana, observation). Despite being food secure Guyana's livestock sub-sector especially poultry industry is not without problems. Some of the activities that limit the expansion of the poultry sector are modernized technologies and the cost of production for meat and eggs.

The major problem is the availability and import cost of raw materials. These raw materials account for more than $80 \%$ of the total feed materials used in the poultry industry. This sector depends heavily on imported agricultural products to produce animal feed. Some of the crops imported are corn and soybean meal. Corn is used as the energy source in animal feed and is used extensively in Guyana (P. DeGroot, Bounty Farm Limited, Guyana, observation). The importation of corn amounts to more than one billion Guyana dollars per year. This has led efforts to focus on alternative raw materials that can be grown locally in large quantities.
The use of cassava to substitute corn in feeds for animal is practiced in many countries (Eruvbetine et al., 2003). Approximately one quarter of the world cassava production is used in the animal feed industry (Prakash, 2006). Cassava, a staple crop used mainly in Guyana as food for the hinterland communities has the potential to replace corn in animal feed.

Consequently, a study was conducted to determine the best ratio at which cassava meal could be incorporated in the diets of broiler chicks and the economic benefits of feeding cassava meal to broilers.

\section{METHODOLOGY}

The variety of cassava utilized was Uncle Mack. Eleven hundred and forty kilograms cassava was washed to dislodge soil particles, chopped and dried on perforated trays according to Hahn et al. (1992). The fresh cassava chips took three days to dry. The dried chips were ground, nutritional analyses conducted and formulation done by Bounty Farm Limited (Tables 1 and 2).

The chicks selected for this trial were of the Cobb breed. Eight hundred one day old broiler chicks were placed in four treatments which were replicated twice. A population of one hundred chicks were randomly selected and placed in each treatment. The rations used include 0 , 5,10 , and $15 \%$ of cassava meal. The completely randomized design was used for this trial. All the chicks were given feed and water ad lib. The trial lasted for a period of six weeks. Body weights were measured weekly, mortality was recorded daily and the feed conversion ratio (FCR) was determined. 
Table 1: Formulation of Cassava Meal Starter Diet

\begin{tabular}{|c|c|c|c|c|}
\hline \multirow{3}{*}{ INGREDIENTS } & DIET I & DIETII & DIET III & DIET IV \\
\hline & STARTER & STARTER & STARTER & STARTER \\
\hline & CONTROL & $5 \%$ * & $10 \% *$ & $15 \% *$ \\
\hline Broken Rice & 720 & 650 & 580 & 500 \\
\hline Soyabean Oil Meal & 340 & 345 & 350 & 360 \\
\hline Fish Meal & 60 & 60 & 60 & 60 \\
\hline Promix & -- & -- & -- & 14 \\
\hline Cassava Meal & -- & 60 & 120 & 180 \\
\hline Broiler Premix 2174 & 20 & 20 & 20 & 20 \\
\hline Liquid Fat & 30 & 34 & 38 & 40 \\
\hline BMD-60 & $200 \mathrm{~g}$ & $200 \mathrm{~g}$ & $200 \mathrm{~g}$ & $200 \mathrm{~g}$ \\
\hline Monteban & $400 \mathrm{~g}$ & $400 \mathrm{~g}$ & $400 \mathrm{~g}$ & $400 \mathrm{~g}$ \\
\hline 3-Nitro & $115 \mathrm{~g}$ & $115 \mathrm{~g}$ & $115 \mathrm{~g}$ & $115 \mathrm{~g}$ \\
\hline Potassium Carbonate & 2 & 2 & 2 & 2 \\
\hline Salt & 5 & 5 & 5 & 5 \\
\hline Calcium Carbonate & 2 & 3 & 3 & --- \\
\hline MonoDical-Phosphate & 18 & 18 & 18 & 16 \\
\hline Lysine & 1 & 1 & 1 & 1 \\
\hline Methionine & 1 & 1 & 1 & 1 \\
\hline Threonine & 0.5 & 0.5 & 0.5 & 0.5 \\
\hline Ethoxyquin & 0.5 & 0.5 & 0.5 & 0.5 \\
\hline Total & 1201.5 & 1201.5 & 1201.5 & 1201.5 \\
\hline
\end{tabular}

* Level of Cassava Meal in Diet

Table 2: Formulation of Cassava Meal Grower Diet

\begin{tabular}{|l|l|l|l|l|}
\hline \multirow{2}{*}{ INGREDIENTS } & DIET I & DIETII & DIET III & DIET IV \\
\cline { 2 - 5 } & STARTER & STARTER & STARTER & STARTER \\
\cline { 2 - 5 } & CONTROL & $\mathbf{5} \%^{*}$ & $\mathbf{1 0} \%^{*}$ & $\mathbf{1 5 \%}$ \\
\hline Broken Rice & 720 & 630 & 615 & 550 \\
\hline Soyabean Oil Meal & 300 & 300 & 285 & 275 \\
\hline Fish Meal & 35 & 60 & 60 & 60 \\
\hline Promix & 20 & 20 & 10 & 30 \\
\hline Cassava Meal & --- & 60 & 120 & 180 \\
\hline Broiler Premix 2174 & 20 & 20 & 20 & 20 \\
\hline Liquid Fat & 55 & 56 & 56 & 56 \\
\hline Stafac 20 & $200 \mathrm{~g}$ & $200 \mathrm{~g}$ & $200 \mathrm{~g}$ & $200 \mathrm{~g}$ \\
\hline Monteban & $400 \mathrm{~g}$ & $400 \mathrm{~g}$ & $400 \mathrm{~g}$ & $400 \mathrm{~g}$ \\
\hline 3-Nitro & $115 \mathrm{~g}$ & $115 \mathrm{~g}$ & $115 \mathrm{~g}$ & $115 \mathrm{~g}$ \\
\hline Potassium Carbonate & 2 & 2 & 2 & 2 \\
\hline Sodium BiCarbonate & 370 & 175 & 180 & 180 \\
\hline Salt & 5 & 5 & 5 & 5 \\
\hline Calcium Carbonate & --- & --- & 2 & 3 \\
\hline MonoDical-Phosphate & 17.5 & 15 & 16 & 14 \\
\hline Lysine & 1.5 & 0.5 & 1 & 2 \\
\hline Methionine & 1 & 0.5 & 0.5 & 0.5 \\
\hline Threonine & 0.5 & --- & 0.5 & 0.5 \\
\hline Ethoxyquin & 0.5 & 0.5 & 1200.4 & 1200.4 \\
\hline Total & 1200.4 & 1201.4 & & \\
\hline & & & & \\
\hline
\end{tabular}




\section{RESULTS}

The nutritional content of the cassava variety, Uncle Mack is shown in Table 3. Compared to rice and corn, cassava had lower protein content. When cassava is used in feed, the protein supplement added is almost double the quantity that is used for rice feed mixture.

\section{Effects of weight gain and feed conversion ratio}

Figures 1 and 2 show the performance of the broilers during the trials. It can be seen that all the treatments that contained cassava flour had weight gains and feed conversion similar or superior to that of treatment 1 (control) which was fed with the standard Bounty feed. Statistical analysis indicated there were no significant differences in body weights amongst the treatments. Broilers growth rates from all feeds followed a similar trend with approximately $2 \mathrm{~kg}$ (body weight) at 42 days of age. In general, broilers fed with rations containing cassava flour preformed equal or better than those fed with bounty feed.

Table 3: Nutritional Content of Cassava variety (Uncle Mack)

\begin{tabular}{|l|c|c|c|}
\hline Nutritional Facts & Cassava (\%) & Rice (\%) & Corn (\%) \\
\hline Crude protein & 3.1 & 7.3 & 7.9 \\
\hline Crude fiber & 4.3 & 10 & 2.9 \\
\hline Fat & 0.5 & 3.5 & 1.7 \\
\hline Calcium & 0.08 & 0.04 & 0.01 \\
\hline Phosphorus & 0.09 & 0.26 & 0.25 \\
\hline Sodium & 0.01 & 0.02 & 0.03 \\
\hline Ash & 1.66 & 4.5 & 1.5 \\
\hline
\end{tabular}

$\square$ ExpectedWeight $\square$ Treat.1 $\square$ Treat.2 $\square$ Treat.3 $\square$ Treat.4

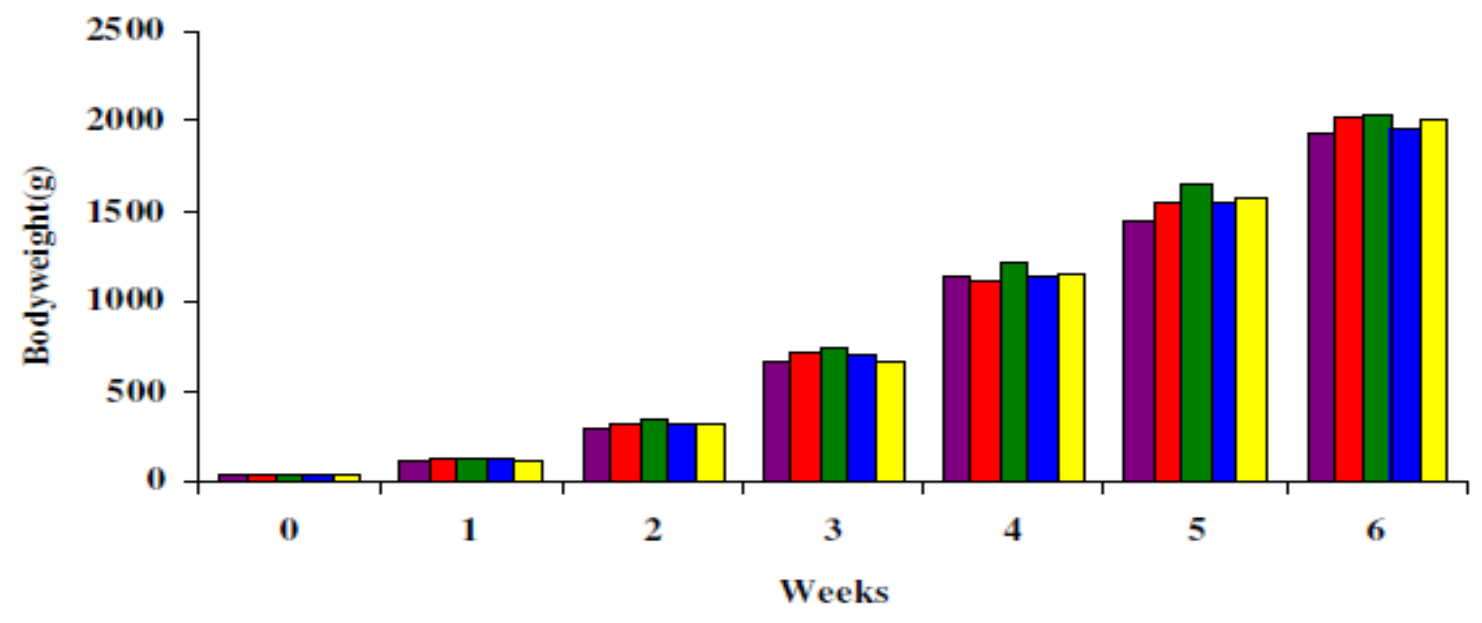

Figure 1: The Growth Rate Chicken

$T_{1^{-}}$Control or $0 \%$ cassava, $T_{2^{-}}-5 \%$ cassava, $T_{3}-10 \%$ cassava, $T_{4}-15 \%$ cassava

The expected body weight for week 1 was 3 times the birth weight

The expected body weight for week 2 was 2.4 times the expected first week weight. The expected body weight for week 3 was $0.34 \mathrm{~kg}$ and for week 4,5 and 6 is $0.45 \mathrm{~kg}$. 
घStandard $\quad$ Treat.1 $\square$ Treat.2 $\square$ Treat.3 $\square$ Treat.4

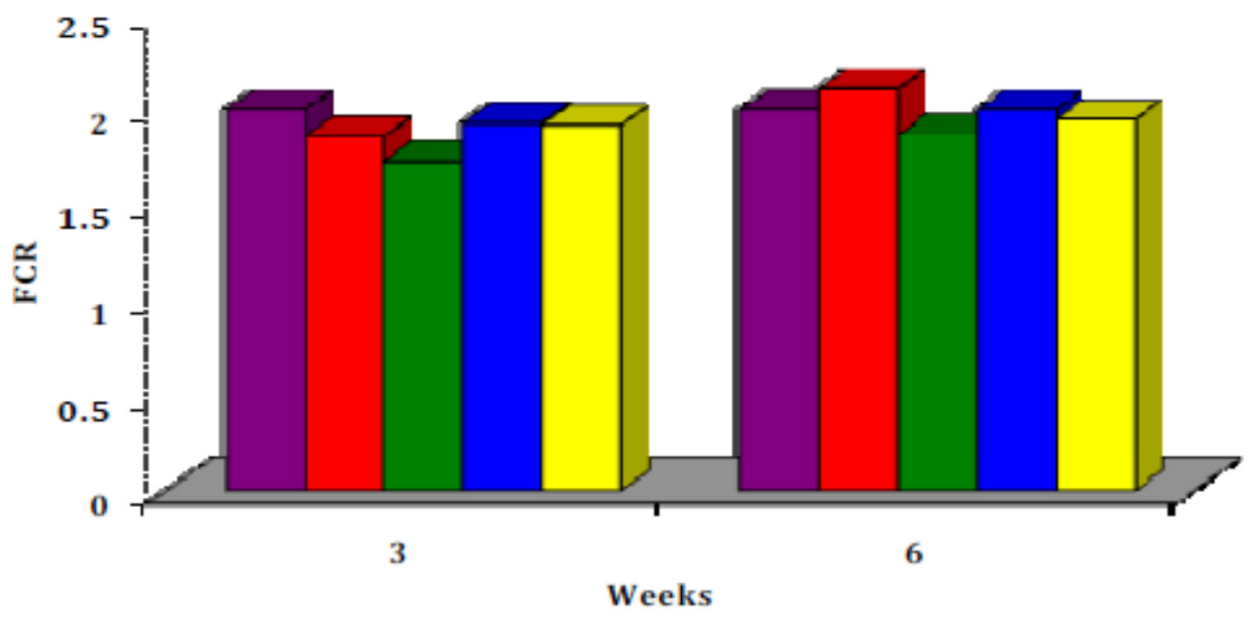

Figure 2: The Feed Conversion Ratio of Chicken

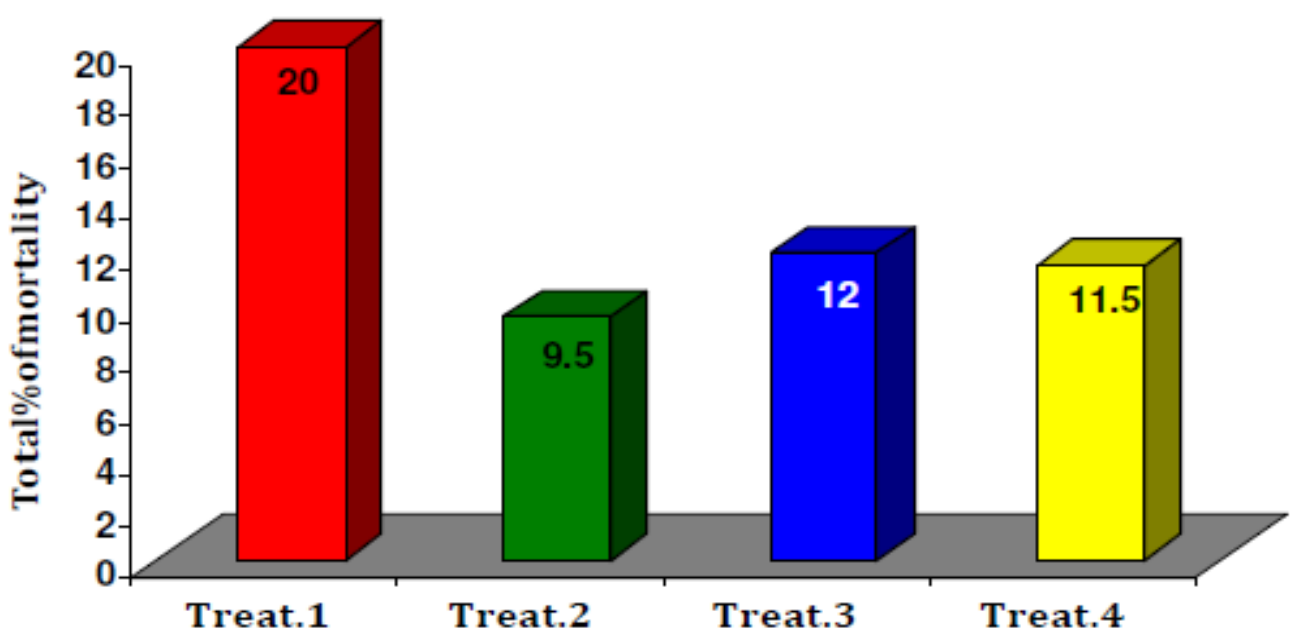

Figure 3: The Mortality Rate of Chicken

\section{Effects on Mortality}

Figure 3 shows the mortality rate of the broilers at the end of the trial. There were no significant difference among the treatments. All treatments exceeded the average standard mortality of $8 \%$. The lowest mortality was recorded for treatment 2 ( $5 \%$ cassava). Deaths were related to those of spiking mortality syndrome, mainly in the third and sixth week.

\section{Feasibility of using cassava in the feed industry}

\section{DISCUSSION}

The results of the study indicated that cassava can be included as an ingredient in poultry feed. The recommended amount is $15 \%$.

From the studies conducted locally, it was found that $1.37 \mathrm{~kg}(3 \mathrm{lb})$ of fresh cassava produce $0.46 \mathrm{~kg}(1 \mathrm{lb})$ of cassava flour. At the current prices of corn $(\mathrm{G} \$ 80 / \mathrm{kg})$ and rice $(G \$ 88 / \mathrm{kg})$, the cost of $1 \mathrm{~kg}$ of cassava flour must be within the range for it to be competitive. This means that the farm gate price for fresh cassava tubers must be approximately $\mathrm{G} \$ 28 / \mathrm{kg}(\mathrm{G} \$ 13 / \mathrm{lb})$.

Ngiki et al. (2014) indicated that there were no significant differences between growth for weight gains and feed 
conversion ratio for birds fed on maize-based feeds and these fed with cassava substitute. Oyebimpe et al. (2006) pointed out that there was no reduction in growth performance when cassava peel meal substituted maize in broiler diets. According to Buitrago et al. (2007), boilers were fed with $50 \%$ cassava flour and integral soybeans had no difference or superior weight gains when compared to those fed with maize and integral soybeans.

Tathawan et al. (2002) and Saentaweesuk et al. (2000) demonstrated that broilers fed on cassava diets showed better health status and required less or no antibiotic treatment when compared to those fed on cereal or grains.

Based on this recommendation and the computation by DeGroot (2009), the total cassava

The other study by Blair (2010b) analyzed the status of risk management and finance along the cassava value chain and suggested ways for the enhancement of the existing risk management mechanism in view of the likely development in the industry.

The first study by Blair (2020a) revealed that yields were relatively low $(7,808 \mathrm{lb} / \mathrm{A}$ compared to 8,922 $\mathrm{Ib} / \mathrm{A}$ for Latin American and Caribbean Countries) and

\section{ACKNOWLEDGEMENT}

The authors are immensely appreciative to the National Agricultural Research and Extension Institute and Bounty Farm Limited for their support on cassava poultry feed research.

\section{REFERENCES}

Blair R (2010a). The actual and potential market for cassava in Guyana: AAACP Paper Series No. 12. FAO.

Blair R (2010b). Risk management and finance along the cassava value chain in Guyana: AAACP Paper Series No.13. FAO.

Buitrago J, Bernardo O, Gil JL and Aparicio H (2007). Cassava root and leaf meals as the main ingredients in poultry feeding: Some experiences in Colombia. In: Howeler, Reinhardt H. (ed.). Cassava research and development in Asia: Exploring new opportunities for an ancient crop: Proceedings of the seventh regional workshop held in Bangkok, Thailand, Oct 28-Nov 1, 2002. CIAT, Cassava Office for Asia, Bangkok, TH. 523-541. requirement for the local poultry feed industry would be 13,560 tons. Blair (2010a) estimated the area under cultivation to be 1924 ha $(4,752 \mathrm{~A})$ with an average yield of $8,754 \mathrm{~kg} / \mathrm{ha}(7,808 \mathrm{lb} / \mathrm{A})$. The annual production was extrapolated to be 16,225 tons. Blair (2010a) also found that $45 \%$ of all cassava production was consumed by the household. This translates to 7301 tons.

The remainder is sold to the local market. No estimate could have been made at this time on the local market demand. Blair (2010a) conducted a study on profiling the actual and potential market for cassava in Guyana. The study sought to assess and quantify the demand for cassava and the main cassava products and current production volumes.

was a severe constraint to the sector. The second study by Blair (2010b) identified marketing and production risks faced by farmers. With regards to production risks, the most prominent were attacks from pests. Based on the above considerations, it is imperative that appropriate actions be undertaken to nullify the constraints identified to enhance production and productivity in Guyana.

Eruvbetine D, Tajudeen ID, Adeosun AT and Olojede AA (2003). Cassava (M. esculenta) leaf and tuber concentrate in diets for broiler chickens. Biores. Tech., 86: 277-281.

Ngiki Y U, Igwebuike JU and Moruppa SM (2014). Effects of replacing maize with cassava root-leaf meal mixture on the performance of broiler chickens. IJST, 3: (6): 352-362.

Oyebimpe K, Fanimao O, Oduguwa $\mathrm{O}$ and Biobaku WO (2006). Response of broiler chicks to cassava peel and maize offal in cashew nut meal-based diets. Arch. Zootec., 55:301-304.

Prakash A (2006). Background paper for the competitive commercial agriculture in Sub-Sahara Africa (CCAA) study.

Cassava: International Market Profile. FAO.

Saentaweesuk S, Kanto U, Juttupornpong S and Harinsut P (2000). Substitute of cassava meal for corn in broiler diets. In: Proc. 38th Kasetsart University Annual Conference: Animal, Veterinary Medicine, Bangkok, Thailand.

Tathawan S, Moonchaisuk S, Tanasrisutara N, Kanto U and Juttapornpong S (2002). A comparative study of corn and cassava diets both supplemented and unsupplemented with antibiotic on performance and mortality rate of broilers. In: Proc.40th Kasetsart University Conference, Kasetsart University, Thailand 